\title{
The Construction Industry Stabilization Committee: Implications for Phase II
}

THE CONSTRUCTION INDUSTRY STABILIZATION COMMITTEE was established by Executive Order 11588 on March 29, 1971. It is a tripartite committee, with unions, management, and the public each having four representatives, and with John T. Dunlop, Dean of the Faculty of Arts and Sciences of Harvard University, as chairman. The labor and management members have alternates-not personal alternates from their own staffs, but officials of other unions and contractor associations having the same stature as the men they replace. Changes in the economic provisions of all new collective agreements in the construction industry require approval by the committee before they can be put into effect. Before most cases come to the committee they are first reviewed by one of a series of craft dispute boards representing branches of the industry. These have labor and management members, but no public members. Some agreements are disapproved by the craft boards before they reach the committee.

By the end of October 1971, the committee had received more than 1,200 cases involving an even larger number of agreements. It had approved the economic adjustments in more than 700 cases and had failed to approve, in whole or in part, the economic adjustments in about 350 others.

According to unofficial statistics, the unweighted average first-year increase in wages and fringe benefits in the cases approved is approximately 
11 percent. For those contracts that include a second year, the average second-year increase approved is approximately 9 percent. For those with a third year, the average increase approved for it is approximately 8 percent. The average first-year increase on contracts negotiated in 1970 was 15 percent, and settlements in the first quarter of 1971 ran above the 1970 level. During 1970, the volume of expenditures for new construction was $\$ 91$ billion; in the first seven months of 1971 it rose to an annual rate of $\$ 103$ billion. To be sure, most of the expansion was in residential construction; nevertheless, it added up to a very large increase in activity that, in the absence of controls, would no doubt have led to higher wage settlements.

The committee has had two other effects. First, there have been fewer strikes in construction in 1971 than in 1970; substantially fewer than half as many strikes have been in progress in each week of the construction season. This development in itself tends to lower construction costs and to bring projects to earlier completion. The reduction in the number of strikes occurs in part because the controls exist and in part because officers of national unions and contractors' associations serving on the committee have taken a hand in settling some of the most difficult negotiations.

Second, the committee has frequently disapproved, often by unanimous action, changes in work rules that add to costs, such as increases in premiums for "high" time and for the use of certain tools, travel and overtime pay, and increases in the required number of foremen. On the other hand, the committee has been more willing to approve increases in base rates where such costly premiums and practices were reduced or eliminated. This policy, which is somewhat analogous to productivity bargaining under the British incomes policy of the late 1960s, is not reflected in the statistics and indeed makes the wage statistics look worse than they should.

The criteria under which the committee operated until October permitted acceptance of economic adjustments "supportable by productivity improvement and cost of living trends, but not in excess of the average of the median increases in wages and benefits over the life of the contract negotiated in major construction settlements in the period 1961 to 1968."1 This limitation was intended to place a ceiling of 6 percent on adjustments that do not involve equity considerations. The criteria further provided that equity adjustments "may, where carefully identified, be considered over the

1. Weekly Compilation of Presidential Documents, Vol. 7 (April 5, 1971), p. 584. 
life of the contract to restore traditional relationships among crafts in a single locality and within the same craft in surrounding localities.",2

It is clear from the difference between the average settlements approved and the 6 percent basic guidepost that the committee has made heavy use of the equity provisions. Some critics make it clear that they expected closer adherence to the 6 percent figure and that in their opinion the equity adjustments have gotten out of hand. Such critics may not realize the extent to which the wage structure in construction had become distorted during the wage explosion of 1968-70.

It is not unusual for the committee to get a case in which the wage rate for skilled carpenters in a particular city in March 1971 was $\$ 5.00$ and the rate for unskilled laborers in the same city was $\$ 6.50$ because the carpenters had last negotiated in 1968 while the laborers had negotiated in 1970. Nor was it unusual in such a case for the committee to approve an increase in wages for carpenters of $\$ 2.00$ over a two-year period, which constituted an increase of almost 20 percent a year. Even in such an extreme case, however, controls can have an effect. In their absence, the new contract might easily have called for an initial increase of $\$ 2.00$ an hour, with more to follow. To the extent that such gross inequities are corrected during the first year of controls, increases in subsequent years can be kept closer to the guidepost figures.

In many cases the consideration of equity also involves the comparison of increases in newly negotiated contracts with deferred increases provided for in previously negotiated contracts. Executive Order 11588 gives the committee power to examine deferred increases to determine whether they are grossly inconsistent with the criteria established in the order. It is silent on the powers of the committee if it finds such a gross inconsistency. The majority of the committee took the view that deferred increases could be prevented from going into effect only by voluntary agreement, and no such agreement has yet been implemented. Clearly, if the new Pay Board establishes control over deferred increases in other industries, the construction committee will want to reconsider this issue. It is far harder to take a tough position on deferred increases when only one industry is being stabilized than it is in the context of a broad stabilization program.

Perhaps the most important aspect of the committee's work begins when it fails to approve a wage increase. It does not formally disapprove the

\section{Ibid.}


agreement, for this would set in motion a cumbersome machinery that might be counterproductive. Instead, it returns the agreement to the parties for renegotiation. The labor and industry members of the committee have often been instrumental in helping to renegotiate agreements that were initially unacceptable. This is particularly difficult for the union members, who must tell local unions that they cannot have increases that their employers are often anxious to pay. Yet this process has been so successful that in seven months of operation there has not been a single strike against a committee decision.

Clearly, it is my view that the committee has been successful. I make this evaluation against the background of incomes policies in the United Kingdom and Canada, where attempts to use all-governmental machinery in dealing with similarly decentralized unions seem to me to have accomplished little or nothing. On the other hand, this judgment clearly will not convince those who believe that one can stop a galloping inflation by slamming on the brakes hard and hoping that all passengers have their seat belts fastened.

Some economists have suggested recently that there is a problem for stabilization agencies in working with the Federal Mediation and Conciliation Service, whose primary aim is to avoid work stoppages, not to restrain inflation. The Construction Industry Stabilization Committee has not had any problems in this area. It has not attempted to use the mediation service to implement its wage policies-one does not ask the chaplain to man the artillery. However, a representative of the mediation service attends each meeting of the committee and is very useful both in keeping the committee informed about developments in the field and in keeping the parties to negotiations informed about the patterns of settlements being approved by the committee in particular areas.

The conflict between wage stabilization and dispute settlement is not created by the mediation service; it is much more fundamental. If there were no mediation service, there would still be strong voices within the legislative and executive branches of government to urge that stabilization policy be breached in order to settle disputes that damage the economy or harm particular groups of producers or consumers. The professional interest of mediators in settling disputes is very weak when compared with these political forces.

What, if any, are the implications of the construction industry experience for Phase II and the new Pay Board? The first, already reflected in the new 
structure, is that a tripartite committee has considerable advantage over an all-government body in implementing its wage decisions, even though the decisions themselves may turn out to be somewhat more lenient.

The second implication is more subtle. It is that the effective functioning of a tripartite board requires the public members to play something of a mediating role. They must convince the union and management members that they are fair-minded and open to persuasion. The committee is fortunate in having a chairman who has the confidence of both sides. In contrast, the labor movement has clearly expressed its strong feeling that most of the public members of the new Pay Board are hostile to it. If the board is to survive, they will have to come to feel that their suspicions are unfounded.

A third lesson is that any general guidepost for compensation must be lower than the desired average increase so as to leave room for equity adjustments. On the other hand, probably no other industry requires equity adjustments as large as those in construction, because no other wage structure starts out in such a mess. I would guess that a spread of 2 percentage points between the guidepost for cases not involving equity and the average increase approved would be generally sufficient, as compared with the spread of 5 percentage points in construction.

Perhaps the most important lesson I would draw is that any control of collectively negotiated increases must involve case-by-case consideration of all agreements. General guideposts may suffice for salaries and for nonunion wages and fringes. However, it would be fatal to take a Galbraithian view of collective bargaining and confine jurisdiction to, say, the 500 settlements covering the largest number of workers. Whatever the case in product markets, it simply is not true in labor markets that the biggest unions are the strongest. Indeed, the opposite sometimes comes closer to the truth: A small union in a strategic position may be the most powerful of all. Moreover, the force of "orbits of coercive comparison," to use the apt phrase of Arthur M. Ross, ${ }^{3}$ means that a high settlement for twenty asbestos workers or ten tile setters could destabilize wages for ten thousand workers in a whole metropolitan area. I am sure that this situation is not confined to construction. The labor movement can tolerate some constraint, particularly if it has a hand in administering it. What it cannot tolerate is a constraint that is not evenhanded - that holds some back while others are free to leap ahead.

3. Arthur M. Ross, "The Dynamics of Wage Determination under Collective Bargaining," American Economic Review, Vol. 37 (December 1947), p. 801. 
Perhaps I have not drawn the right conclusions from the construction experience, or perhaps those I have drawn are less applicable elsewhere than I believe. Even if they are correct, I have no hope that even the best control system that can be devised can survive indefinitely. At some point, it is certain to break down, either because it becomes lax or because it is successfully defied. The most difficult challenge is to achieve changes in bargaining structure while controls are in effect that will improve wage determination after controls are lifted. For construction, these changes in part involve the consolidation of bargaining areas and the encouragement of multicraft agreements so as to reduce the leapfrogging that has plagued the industry. The committee has been willing to pay a price for such reforms in considering wage increases. The analogous objectives elsewhere in the economy will have to be defined on an industry-by-industry basis.

\section{Discussion}

Arthur Okun: The construction pay panel had a unique and very difficult problem, trying to stabilize a single industry in an otherwise laissez faire wage system. I have no desire to second guess its actions. But I do worry about the picture of the labor market that Albert Rees draws. It confirms my fears that we have been experiencing more of a wage-wage spiral than a wage-price spiral.

In that world, as Rees depicts it, market conditions do not seem to have much determining influence, at least in the short run. Wage explosions can occur for no obvious reason. Construction unions have monopoly power, to be sure, but they have had it for a long time, and that power should have been expected to show up in higher wage levels rather than in much greater rates of wage increase in the last few years. We are led to the notion that wage rate wars can break out, much as gasoline price wars do. These seem to occur when craft unions deal with small employers, not only in construction but also among printers, teamsters, and dockworkers. Perhaps it reflects the absence of countervailing power on the management side, which would tend to moderate the settlements.

The key element in this picture is that any union that gets an unusually big settlement-for any reason or simply by chance-exerts some mag- 
netism on the overall pattern of wages in the future. That in itself would produce an inflationary bias in the wage determination process. Rees' picture may well depict a fact of life. But, if so, it is an unhappy fact that ought to be changed by institutional reform or by controls. It should not be dignified as "equity." I don't view it as equity that, when one chicken gets out of the coop, all the others have to be let out, too.

The inequity and the anomaly occur when laborers leapfrog over a $\$ 5$ carpenters' wage to get a $\$ 6.50$ wage. The aim of a restraint program is to prevent that first round of leapfrog from taking place or to end the game as soon as possible if it does occur. Consider a currently relevant example: Steel, aluminum, and other contracts in manufacturing signed before $\mathrm{Au}-$ gust 15 work out to nearly 10 percent a year. These industries bargained in a world of rapid inflation; if, in fact, inflation slows to $2 \frac{1}{2}$ percent, the workers will get a windfall. Now if new union wage settlements are forced down to $5 \frac{1}{2}$ percent, workers covered by them will get a respectable 3 percent rise in real wages. They will not get the windfall the steelworkers got, to be sure; but they will not be squeezed. I see no economic or moral case for an "equity adjustment" in such instances, even if history demonstrates that several settlements taking place after November 15 have regularly matched the steel settlement in past wage rounds. Indeed, if "equity adjustments" are used to rationalize large wage increases in the union sector, the $5 \frac{1}{2}$ percent limit will break down in the unorganized sector, because those employers have to maintain the good will of their workers by treating them as well as workers in the union sector are treated.

Having said all this, I must recognize the real-world relevance of Rees' warnings. If the wage rate target is set too low, if the controllers try too hard, if they make no exceptions, the whole system may explode. The wage controls must look equitable enough to convince most people that the Pay Board is fair. But they also must be tough enough to yield progressive deceleration of inflation.

\section{General Discussion}

Paul Samuelson reported two reasons he had heard that would account for a recent increase in the monopoly power of construction unions and hence for their escalating rates of wage increase: First, the mix of construction has moved toward bigger projects, which afford the unions more 
leverage. Second, no employer has successfully taken a construction strike in recent years, and employers have learned through bitter experience that it is disastrous to take a strike. Apparently, one key reason is that any construction worker with an automobile can hunt work in a nearby area when a strike shuts down building in his city.

Charles Holt referred to Rees' observation that the most difficult challenge is to effectuate changes in bargaining structure while controls are in effect that will improve the wage determination process after controls are lifted. For construction, this task means the consolidation of bargaining areas and the encouragement of multicraft agreements so as to reduce wage rate leapfrogging. He asked how far Rees was willing to extend this principle. In Sweden and some other countries, collective bargaining is conducted essentially at the national level for all industries and occupations.

Rees responded that he wished to push the principle far enough to equalize the strength of the employers so that union victories in strikes are not automatic. That desire stopped far short of the Swedish pattern, which is alien to the bargaining conditions in the United States. In response to Okun's discussion of equity, Rees said that the comparisons that have to be taken seriously reflect traditional close relationships, similar to the fact that assistant professors are not paid more than associate professors. Two people doing essentially the same job, one working in a basic steel plant and one working in a steel fabricating plant, would consider it inequitable to have different wage rates. That type of inequity can be handled either by rolling back the basic steel settlement or by letting the fabricators move up in line. The former course seemed impracticable, and hence, he felt that the Pay Board would be obliged to allow a catch-up, even though the fabricators' contracts come up during the control period.

Peter Henle mentioned other aspects of the structure of bargaining that can affect the relative strength of unions and employers. In construction, local bargaining clearly helps the union side. The local union is stronger than the local group of employers, and furthermore the various locals of the same union tend to compete to outdo one another in the size of the settlements. These elements are absent in large manufacturing industries such as steel and autos. An element on the employers' side in large manufacturing units is that union strike funds would be rapidly depleted in the event of a large strike. Lawrence Krause mentioned the Davis-Bacon act as one unique feature that increased the bargaining power of unions in construction. 
Several participants commented on Rees' estimate that an additional 2 percentage points of wage increase had to be allowed for equity adjustments. Fellner pointed out that an increase in the economy-wide average of wage increases by 2 percentage points as the result of the equity adjustments must mean that Rees expects them to be extremely large in some instances. Rees pointed out that, in the construction case, some increases as large as 20 percent seemed justified on equity grounds. Okun was concerned that adjustments of this size in the collective bargaining sector would be discriminatory relative to unorganized workers, who would be basically governed by the $5 \frac{1}{2}$ percent guideline and whose pay decisions would not be reviewed on a case-by-case basis by the Pay Board. Samuelson believed that large increases in the union sector would create upward pressures on nonunion employers who set those wages in such a way as to eliminate any appeal of unionization to unorganized workers. It was pointed out, on the other hand, that average nonunion wage increases have been considerably below union increases of late, reversing an earlier pattern; if this situation has been viable in an uncontrolled economy, it may continue to be viable. 